International Journal of Instruction e-ISSN: 1308-1470 • www.e-iji.net

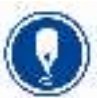

October $2020 \bullet$ Vol.13, No.4

p-ISSN: 1694-609X

$$
\text { pp. 133-144 }
$$

Received: 18/07/2019

Revision: 25/03/2020

Accepted: $14 / 04 / 2020$

OnlineFirst:08/07/2020

\title{
Don't Forget the Field Trip! The Professional Impact on K-12 Teacher Preparation and Retention
}

\author{
Shirley Ann Dawson \\ Assoc. Prof., PhD., Weber State University, Utah, USA, shirleydawson@weber.edu \\ Patrick Allen Leytham \\ Assoc. Prof., Touro University Nevada, Nevada, USA, Patrick.Leytham@tun.touro.edu
}

$\mid$

Field trips are an evidence-based practice to improve learning in K-12 students. Educator training traditionally includes several evidence-based practices to prepare teachers. While the power and impact of field trips for education and recreational purposes for K-12 students is widely accepted, less understood is the role of field trips for college students preparing to become educators. The current investigation is part of an ongoing multi-year survey exploring the impacts of attending a multiday professional convention for teachers. Online surveys were distributed to participants to measure the influence of a conference attendance field trip on new teacher retention rates, academic performance, and professional networking. Both undergraduate and graduate students were included as participants and responded to Likert-type and open-ended questions. Results indicate a positive impact on teacher retention for current and future educators, higher academic performance while attending university, and increased professional involvement opportunities. Future studies are needed to address the limitations of self-reporting.

Keywords: field trips, educator preparation, teacher retention, teacher preparation, learning

\section{INTRODUCTION}

Field trips are routinely viewed as exploratory expeditions that engage young learners and provide beneficial learning environments for students in early childhood (Aronson, 2011) and K-12 programs (Whitesell, 2016). For adult learners in educator preparation programs (EPP), however, the impact of field trips on teacher retention is generally overlooked in favor of focus on curriculum preparation (Morentin \& Guisasola, 2015) or context (Giles, 2017). The field trip experience during educator preparation could be considered as a potential "mighty change" agent. A mighty change instigated by a small act was proffered by Lorenz (1993) in musings that changes in world weather could be triggered from a single seagull flapping its wings. This paper explores changes in new 
teacher retention, academic performance, and professional involvement activated by a professional field trip.

Although cognitive, educational, and personal advantages of field trips for students are documented (DeWitt \& Storksdieck, 2008), less understood is the impact of field trips during preparation on professional outcomes for K-12 educators. Involvement in field trips to professional conventions may be the bridge for new educators between college preparation and career practice. Such impact may be a small but mighty change (Lorenz, 1993) needed to support entering teachers and address educator shortages (Goldring, et al., 2014).

\section{Educator Preparation and Attrition}

Traditional university based EPP have a large influence on student knowledge and on teacher employment. It often includes coursework in various disciplines to develop strong content knowledge (Friedrichsen, et al. 2009) such as literacy, numeracy, science, arts, and civics, as well as pedagogy, instructional design, planning, alignment, assessment, and technology (Hockett \& Doubet, 2014; Penuel et al., 2007; Tomlinson \& Imbeau, 2010; Wiggins \& McTighe, 2011; William et al., 2004) to facilitate learning for the wide diversity of students present in today's classrooms (Krathwohl, 2002). Students taught by certified teachers experience better academic outcomes than students who do not have this opportunity (Darling-Hammond et al., 2005; Henry et al., 2014; Whitford et al., 2018), and university prepared teachers are very effective in meeting the needs of diverse children, including those with disabilities (Sutcher et al., 2016). The benefits of educational practice to support instruction and enhance coursework are widely recognized in EPPs (Conderman et al., 2013). Despite the benefits of EPPs, new educators still require supports in order to apply what was learned in their programs (Billingsley, 2005). New special educators, for example, may need effective professional development and support for learning what it means to be a professional (Billingsley, 2016). Needed ongoing support for beginning educators suggests EPPs should actively identify additional ways to better prepare teachers so they remain within the field.

Teacher employment rates are influenced by policies, attrition, and teacher shortages. Although policies specifically targeted to reduce attrition through bonuses or school debt forgiveness can reduce shortages (Cowan et al., 2016), the need for trained teachers is critical and has not diminished but rather increased to the point of horrific and threatening teacher shortages (Aragon, 2016). Teacher attrition is a significant cause of teacher shortages. The influence of educator preparation is especially important when considering that approximately twice as many beginning teachers without proper certification leave the field as those with certification. Attrition is more problematic for early career teachers than for veteran teachers (Goldring et al., 2014; Ingersoll, 2012). By the third year of teaching only $80 \%$ of new educators are still teaching (Goldring et al., 2014). These new teachers experience a "turbulent landing" (Kardos \& Johnson, 2010) leading to a $17 \%$ attrition rate for teachers who stop teaching on or before five years (Aragon, 2016). To alleviate the challenges faced by new teachers, induction programs were developed and designed. Induction programs are widely used in all 50 
states (Sindelar et al., 2010) to curb shortages and support new teachers. Similar teacher shortages are found in Canada, Estonia, China, and the Netherlands (Aristorenas, 2018).

Previously, induction programs focused on content, culture and personal characteristics (Billingsley, 2005), but recently Billingsley (2016) identified a fourth area, professionalism, that must be addressed in induction and preparation stages. While current education reform movements can be viewed as moving teachers towards "deprofessionalism", professionalism is a way to support new teachers with collective action, discourse, vigilance, and power (Anderson \& Cohen, 2015). Emerging dissertation work showed a relationship between teacher retention and professional organizations. Teachers who participate in professional organizations indicate having an increased commitment that influences retention and attrition (Holliman, 2012). Educator preparation that includes attendance at a professional convention could help reduce teacher attrition by increasing participation or commitment to the profession.

\section{Field Trips}

Field trips are not the same as field or practicum experiences. In practicum experiences preparing teachers demonstrate and practice previously obtained content knowledge and skills in supervised educational settings over extended time. A field trip is a firsthand visit to acquire additional knowledge in authentic settings for a brief period. Scientific inquiry supports the use of field trips for students all over the world (Amosa et al., 2015) and through various modalities, such as school journeys (Behrendt $\&$ Franklin, 2014) or virtual trips (Adedokun et al., 2015). In their review of key findings over a 30-year period DeWitt and Storksdieck (2008), found that field trips can produce significant formidable effects on student learning. The field trip allows for experiential learning that cannot be duplicated in the classroom (Behrendt \& Franklin, 2014).

Although field trips have long been a capstone feature of many K-12 classes, its use tapers off as students age and is almost extinct by college (Rebar, 2012). The benefits of university field trips include educational, cognitive, personal, employment, and professional gains. College students report that traditional off campus field trips strengthen authentic and concrete experiences, reflections, and actions that support theory and book learning (Lei, 2010). Improved content knowledge (Eksteen \& Reitsma 2015; Kushins, 2015), improved attitudes (Eksteen \& Reitsma 2015), increased conceptual understanding (Morentin \& Guisasola, 2015), and increased critical thinking skills (Kisida et al., 2016) are some verified cognitive gains. Personal benefits include learning more about oneself (Kushins, 2015) and promoting personal development (Behrendt \& Franklin, 2014). Personal knowing and feeling experiences from field trips change the student (Vascellaro, 2011). University field trips are frequently tied to preparation for employment future careers (Eksteen \& Reitsma, 2015; Morentin \& Guisasola, 2015) and opportunities for continuing professional development (Eksteen \& Reitsma, 2015; Kushins, 2015; Lei, 2010; Morentin \& Guisasola, 2015; Vascellaro, 2011). The use of trips for professional development is increasing (Achen et al., 2019; Suacamram, 2018). One type of professional field trip is attendance at a professional convention or conference. From such field trips, students are exposed to networking, 
content, and professional experiences. Previous research has not specifically addressed the impact on retention for preservice teachers attending professional field trips

\section{METHOD}

To rekindle the advantages of what Wheeler (2011) called a "tradition in jeopardy" (p. 52 ), an investigation was undertaken to determine the influence of convention attendance on educator retention and attrition rates, academic performance, and professionalism. The current non-experimental mixed methods investigation is part of an ongoing multi-year survey exploring the impacts of professional involvement for preservice educators. A mixed method investigation was selected to allow for both quantitative and qualitative analysis. Questions asked in the study are do preservice educators who attend a professional convention experience better retention rates, have better academic grades, and have increased professional experiences.

\section{Instruments}

Following convention attendance, participants responded to an online survey using the university's data collection system. The online survey consisted of 19 demographic, 18 Likert, and four open-ended questions designed by teacher education faculty at the university to determine the influence of field trip attendance to a professional convention on new teacher academic preparation, retention, and professional involvement. Based on previous research use within the department, the survey was selected for the current research. Likert questions were on a five-point scale with anchors of not at all, a little, somewhat, a lot, and not applicable. From the 160 electronic surveys emailed to both current (15) and past students (145) who were student members of a national professional organization, 96 students responded $(60 \%)$ yielding $69(43 \%)$ useable surveys. Such rates are good to adequate (Groves, 2006) given the overall declining rates for survey research and the impacts of time, cost, importance, bias, and participant sameness (Sturgis et al., 2017).

\section{Participants}

Study participants include graduate and undergraduate students enrolled in a teacher education program who attended a national professional convention in a distant city. All preservice teachers who participated in at least one such type of field trip were invited to participate and gave express consent to take part in the study. Undergraduate and graduate students ( $n=69$ useable surveys received) were enrolled in an educator preparation program (EPP) at a traditional university. The composition of the student body at the university is more alike than diverse, according to university records. The four-year accredited EPP is very homogenous in student demographics as most students in this program are female, Caucasian, similarly aged, and middle class. Average selfreported (from survey) grade point average (GPA) of all participants was 3.63. Most participants $(n=50)$ were members of a national teacher professional organization and many $(n=35)$ had attended a national conference. Undergraduates had the opportunity to attend a professional conference during their final semester and graduate students could attend during their last year of their preparation program. To secure travel funding (airfare and hotel) to attend the professional conference, faculty advisors supported 
students as they engaged in several fundraisers each year and applied for travel grants. Students personally paid for meals (around \$75.00 USD) and the convention registration fee (approximately $\$ 300$ ).

Table 1 provides a description of the demographic makeup of the participants. Among those currently employed as educators, approximately $80 \%$ were teaching in public schools, $15 \%$ in charter schools, and $6 \%$ in private schools. The range of teaching experiences for present teachers (either past or current students) was from one to seven years with an average of 3.3 years spent teaching.

Table 1

Demographic Information for Current and Previous Students

\begin{tabular}{cll}
\hline Category & $\begin{array}{l}\text { Current } \\
(\mathrm{n}=37)\end{array}$ & $\begin{array}{l}\text { Previous } \\
(\mathrm{n}=30) 32\end{array}$ \\
\hline Field of Teaching/Licensure Designation & & 1 \\
Early Childhood Education & 1 & 1 \\
Elementary Education & 1 & 1 \\
Secondary Education & - & 19 \\
Special Education & 32 & 6 \\
Family Studies & 1 & - \\
Collegiate Level & 2 & 1 \\
Dual Certification & - & 1 \\
Not Currently Teaching & - & 2 \\
Other & & \\
Seraduate Pursuit & - & 19 \\
Seeking Masters Degree & - & 11 \\
Seeking Teaching Certificate & & 19 \\
Teacher & - & 2 \\
Mentor & - & 1 \\
Administrator & - & 3 \\
Paraprofessional & - & 7 \\
Teacher Leader & - & - \\
Other & - & \\
\hline
\end{tabular}

\section{Procedures}

Undergraduates were informed of the field trip opportunity during introductory teacher education courses (freshman and sophomore students) and again during orientation meetings upon formal admittance to teacher education programs (sophomore and junior students). Graduate students were apprised of convention travel by university instructors. All students paid professional organization membership dues out of pocket (ranging from $\$ 5.00$ to $\$ 52.00$ ) and agreed to adhere to university travel policies regarding decorum and attendance. Students were required to attend general sessions at the convention but had autonomy in selecting breakout sessions. 


\section{FINDINGS}

Quantitative responses were analyzed for descriptive and statistical differences using commercial software to determine attrition or retention rates and academic achievement. Attrition and retention rates were determined from current students' projection of the number of years they plan to teach and past students reporting the number of actual teaching years completed. The role of professionalism was analyzed using qualitative methods. Open-ended responses to survey questions were individually read twice before undergoing deeper analysis. Comments were initially sorted into main themes of career, knowledge, and relationships, based on common words such as career, professional, knowledge, experience, networking, involvement, and support. Comments were then reread to assure placement in themes. From the initial sorting of themes, four overarching constructs of professionalism were discovered. These professional constructs were career support, academic support, learning, and involvement.

Retention and attrition rates of current or future educators who traveled to a professional convention were higher than national data figures for current educators (see Table 2). Of the 57 participants, 40 responded to the question of their future career plan: three more years $(n=1)$, five more years $(n=1)$, more than five years $(n=8)$, and until retirement $(n=30)$. When compared to the national data (see Table 2$)$, the longevity percentage of the participants in our study are higher $(75 \%)$. The construct related to rates was career support. In support of career longevity, participants listed conference attendance as "backing my future career as a teacher" and providing "access to additional resources related to my career choice that I otherwise would not have". Such opportunities to "gain professional experience" "ultimately lead to increased exposure to professional development opportunities, interaction with other professionals, as well as students and their families".

Table 2

Comparisons of Retention and Attrition Rates among Educators

\begin{tabular}{lll}
\hline Rate & National Data & Educators Attending Professional Conference \\
\hline 3 year Retention & $80 \% *$ & $100 \% \dagger$ \\
5 year Attrition & $17 \% * *$ & $0 \% \dagger$ \\
Longevity & 15 years $* * *$ & $71 \%$ until retirement $\dagger$ \\
\hline
\end{tabular}

Note: $\uparrow$ Rate calculated using actual and projected teaching years

*Goldring et al., 2014, **Aragon, 2016, ***Lueken, 2017

Academic performance was measured using student self-reported grade point average (GPA). The GPA of participants $(\mathrm{n}=35)$ who attended a professional convention $(m=$ 3.72 , sd $=.1895)$ was significantly higher $(t=2.829, p \leq .01)$ than the GPA of participants $(\mathrm{n}=33)$ who did not attend $(m=3.56, \mathrm{sd}=.2884)$. The construct of academic support is aligned the above academic performance results. Convention attendance provided support to "do better in my studies" and "be a critical thinker and problem solver". In further support of academic support participants listed "valuable learning". Nearly one third of participants mentioned the amount of knowledge received from convention attendance. "I received insight that I couldn't have somewhere else." "I 
have learned a lot and been exposed to new experiences." Professional learning from the trip was an "amazingly educating experience".

Opportunities for professional involvement was the final identified construct. "Networking with other students and professionals is important." Through convention attendance, participants met "a wide range of people in the field I am pursuing" and "met many people and made friends that became somewhat of a support group". These "valuable friendships and connections" carried into early career mentorships. The benefits of career and academic support, learning, and networking were worth the travel costs for $94 \%$ of those who attended the conference. "It was a small amount of money for how much I learned and interacted with my fellow students.".

\section{DISCUSSION}

The many benefits of field trips are not solely limited to K-12 students. The power and impacts of field trips extend to current college students and into their future teaching careers. As demonstrated by this study, current and future educators who participate in a college field trip to a professional convention benefit from improved employment rates, a higher GPA, and opportunities for professional networking.

Attendance at a professional convention yielded longer career plans, lower attrition figures, and higher retention rates for beginning teachers when compared to national data (Aragon, 2016; Goldring et al., 2014). The relationship between convention attendance and improved employment data seems to be dual sided. First, attendance at the convention provides access and exposure to information not otherwise available. Not only was previous classroom instruction cemented, but preparing teachers noted learning experiences unique to the travel that extended traditional education. Second, attendance introduces professional networking associations. These interactions with other professionals may keep new teachers connected to mentors and supporters. The combination of increased knowledge with increased networking for new teachers may be the small but mighty change (Lorenz, 1993) needed to stem teacher shortages (Goldring et al., 2014) and support new teachers.

A significantly higher GPA suggests that students who engage in field trips to attend professional conventions experience valuable cognitive benefits. This finding supports gains found in earlier work for improved learning connections (Lei, 2010), content knowledge (Kushins, 2015), and understanding (Morentin \& Guisasola, 2015). Comments by students that learning was improved through critical thinking and problem-solving underscores the power of field trips to produce formidable learning outcomes (DeWitt \& Storksdieck, 2008) and change the student (Vascellaro, 2011).

\section{LIMITATIONS AND IMPLICATIONS}

Limitations of the study include participant response rate, self-reporting of GPA, and potential validity and reliability concerns with the survey. The inherent nature of survey research creates concerns in bias for those who respond to surveys and those who ignore invitations to participate. As the group under investigation (students in EPP at a traditional university) was largely homogenous and the return rate was above $40 \%$ 
concerns of non-response bias is mitigated (Sturgis, et al., 2017). Self-reported GPA can be problematic (Standish, 2018) however there was no benefit or incentive to provide GPA and all participant groups (graduate, undergraduate, teaching, preparing to teach, non-responders) could similarly inflate or deflate GPA. Finally, an exploratory factor analysis was not conducted on the surveys.

The implications of offering a field trip experience to professional conference during educator preparation are exciting. Given the current teacher shortage situation (Aragon, 2016) the results offer a pathway not previously considered in ensuring trained and committed teachers in classrooms. Work such as this begins to provide support for Billingsley (2016) introducing of professionalism as a key component in EPPs. Further investigations are currently sought to more fully examine the use field trips in teacher training programs and the role membership in professional organizations as a university student.

\section{CONCLUSION}

Field trips are viewed as supporting young student learning, but their use could provide a mighty change in the professional preparation of adult learners as they become teachers. Given the critical need for trained teachers in schools today the use of field trips to increase retention, academic performance, and opportunities for networking is worthy of exploration. Recommendations for educational practice in preparing future teachers include attending professional conventions and networking with other educators in professional settings. This multi-year mixed methods study found substantial differences in the planned and actual retention and attrition rates of new teachers who attended a profession convention during preparation. Significant improved self-reported GPA rates were corroborated by participant statements of improved thinking, problemsolving, and knowledge skills. Increased career longevity and learning were bolstered by learning and networking opportunities. Study findings warrant further investigation into the long-term effects on teacher retention and implications for educator preparation.

\section{REFERENCES}

Achen, R. M., Warren, C., Fazzari, A., Jorich, H., \& Thorne, K. (2019). Evaluating graduate student out-of-class learning: The professional field trip. International Journal of Teaching and Learning in Higher Education, 31(1), 96-107.

Adedokun, O. A., Liu, J., Parker, L. C., \& Burgess, W. (2015). Meta-analytic evaluation of a virtual field trip to connect middle school students with university scientists. $J$. of Science Education and Technology, 24(1), 91-102. doi:10.1007/s10956-014-9524-6.

Anderson, G., \& Cohen, M. I. (2015). Redesigning the identities of teachers and leaders: A framework for studying new professionalism and educator resistance. Education Policy Analysis Archives, 23(85), 1-29. doi:10.14507/epaa.v23.2086.

Amosa, A. A., Ogunlade, O. O., \& Atobatele, A. S. (2015). Effect of field trip on students' academic performance in basic technology in Ilorin Metropolis, Nigeria. Malaysian Online Journal of Educational Technology, 3(2), 1-6. 
Aragon, S. (2016). Teacher shortages: What we know. Teacher shortage series. Denver, CO: Education Commission of the States.

Aristorenas, M. (2018). Solving the teacher shortage crisis: How some countries are working on it. Top of the Class Newsletter by National Center on Education and the Economy. Retrieved from http://ncee.org/2018/09/solving-the-teacher-shortage-crisis/.

Aronson, S. S. (2001). Field trips: Planning for maximum benefit, minimum risk. Exchange, 139, 43-47.

Behrendt, M., \& Franklin, T. (2014). A review of research on school field trips and their Value in education. Int. J. of Environmental and Science Education, 9(3), 235-245.

Billingsley, B. S. (2005). A leader's framework for supporting new teachers. Journal of Special Education Leadership, 18(2), 3-7.

Billingsley, B. (2016, April). Supporting early career special educators. Presented at the Council for Exceptional Children Convention, St. Louis, MO.

Conderman, G., Johnston-Rodriguez, S., Hartman, P., \& Kemp, D. (2013). Preparing preservice secondary special educators. Preventing School Failure, 57(4), 196205. doi:10.1080/1045988X.2012.679326.

Cowan, J., Goldhaber, D., Hayes, K., \& Theobald, R. (2016). Missing elements in the discussion of teacher shortages. Educational Researcher, 45(8), 460-462. doi:10.3102/0013189X16679145.

Darling-Hammond, L., Holtzman, D. J., Gatlin, S. J., \& Heilig, J. V. (2005). Does teacher preparation matter? Evidence about teacher certification, Teach for America, and teacher effectiveness. Education Policy Analysis Archives, 13(42), 151. doi:10.14507/epaa.v13n42.2005.

DeWitt, J., \& Storksdieck, M. (2008). A short review of school field trips: Key findings from the past and implications for the future. Visitor Studies, 11(2), 181-197. doi:10.1080/10645570802355562.

Eksteen, M. J., \& Reitsma, G. M. (2015). Field trips as an intervention to enhance pharmacy students' positive perception of a management module in their final year: A pilot study. African J. of Heal. Prof. Education, 7(2), 212-215. doi:10.7196/AJHPE.436.

Friedrichsen, P. J., Abell, S. K., Pareja, E. M., Brown, P. L., Lankford, D. M., \& Volkman, M. J. (2009). Does teaching experience matter? Examining biology teachers' prior knowledge for teaching in an alternative certification program. Journal of Research in Science Teaching, 46(4), 357-383. doi:10.1002/tea.20283.

Giles, A. (2017). Teaching pre-service teachers about belonging. International Journal of Whole Schooling, Special Issue, 17-25. 
Goldring, R., Taie, S., \& Riddles, M. (2014). Teacher attrition and mobility: Results from the 2012-13 teacher follow-up survey (NCES 2014-077). Washington, DC: National Center for Education Statistics.

Groves, R. M. (2006). Nonresponse rates and nonresponse bias in household surveys. The Public Opinion Quarterly, 70(5), 646-675. doi:10.1093/poq/nfl033.

Henry, G. T., Purtell, K. M., Bastian, K. C., Fortner, C. K., Thompson, C. L., Campbell, S. L., \& Patterson, K. M. (2014). The effects of teacher entry portals on student achievement. J. of Teacher Education, 65(1), 7-23. doi:10.1177/0022487113503871.

Hockett, J. A., \& Doubet, K. J. (2014). Turning on the lights: What pre-assessments can do. Educational Leadership, 71(4), 50-54.

Holliman, S. L. (2012). Exploring the effects of empowerment, innovation, professionalism, conflict, and participation on teacher organizational commitment. Retrieved from https://search.proquest.com/docview/1292971005? accountid=28843

Ingersoll, R. M. (2012, May 16). Beginning teacher induction: What the data tell us. Education Week, 93(8), 47-51. doi:10.1177/003172171209300811.

Kardos, S. M., \& Johnson, S. M. (2010). New teachers' experiences of mentoring: The good, the bad, and the inequity. Journal of Educational Change, 11(1), 23-44. doi:10.1007/s10833-008-9096-4.

Kisida, B., Bowen, D. H., \& Greene, J. P. (2016). Measuring critical thinking: Results from an art museum field trip experiment. Journal of Research of Educational Effectiveness, 9(1). doi:10.1080/19345747.2015.1086915.

Krathwohl, D. R. (2002). A revision of Bloom's taxonomy. Theory into Practice, 41(4), 212-218. doi:10.1207/s15430421tip4104_2.

Kushins, J. (2015). Pedagogical souvenirs: An art educator's reflections on field trips as professional development. International Journal of Education \& the Arts, 16(20), 1-19.

Lei, S. A. (2010). Field trips in college biology and ecology courses: Revisiting benefits and drawbacks. Journal of Instructional Psychology, 37(1), 42-48.

Lorenz, E. (1993). The essence of chaos. United Kingdom: UCL Press.

Lueken, M. F. (2017). (No) Money in the bank: Which retirement systems penalize new teachers? Thomas B. Fordham Institute, Washington, DC. Retrieved from https://fordhaminstitute.org/national/research/no-money-bank-which-retirement-systemspenalize-new-teachers.

Morentin, M., \& Guisasola, J. (2015). The role of science museum field trips in the primary teacher preparation. International Journal of Science and Mathematics Education, 13(5), 965-990. doi:10.1007/s10763-014-9522-4. 
Penuel, W. R., Fishman, B. J., Yamaguchi, R., \& Gallagher, L. P. (2007). What makes professional development effective? Strategies that foster curriculum implementation. American Edu. Research Journal, 44(4), 921-958. doi:10.3102/0002831207308221.

Rebar, B. M. (2012). Teachers' sources of knowledge for field trip practices. Learning Environments Research, 15(1), 81-102. doi:10.1007/s10984-012-9101-y.

Sindelar, P. T., Heretick, J., Hirsch, E., Rorrer, A., \& Dawson, S. A. (2010). What district administrators need to know about state induction policy. Journal of Special Education Leadership, 23, 5-13.

Standish, W. R., III. (2018). A validation study of self-reported behavior: Can college student self-reports of behavior be accepted as being self-evident? (Unpublished doctoral dissertation). NC State University, USA.

Sturgis, P., Williams, J., Brunton-Smith, I., \& Moore, J. (2017). Fieldwork effect, response rate, and the distribution of survey outcomes a multilevel meta-analysis. Public Opinion Quarterly, 81(2), 523-542. doi:10.1093/poq/nfw055.

Suacamram, M. (2018). Developing creativity and entrepreneurship of undergraduate students through a field trip overseas. International Journal of Instruction. 12(1), 591606. doi:10.29333/iji.2019.12138a.

Sutcher, L., Darling-Hammond, L., \& Carver-Thomas, D. (2016). A coming crisis in teaching? Teacher supply, demand, and shortages in the U.S. Palo Alto, CA: Learning Policy.

Tomlinson, C. A. \& Imbeau, M. B. (2010). Leading and managing a differentiated classroom. Alexandria, VA: Association for Supervision and Curriculum Development.

Vascellaro, S. (2011). Out of the classroom and into the world: Learning from field trips, educating from experience, and unlocking the potential of our students and teachers. New York, NY: The New Press.

Wheeler, G., (2011). Field trips: Tradition in jeopardy. Education Digest, 76(9), 52-55.

Whitesell, E. R. (2016). A day at the museum: The impact of field trips on middle school science achievement. Journal of Research in Science Teaching, 53(7), 10361054. doi:10.1002/tea.21322.

Whitford, D. K., Zhang, D., \& Katsiyannis, A. (2018). Traditional vs. alternative teacher preparation programs: A meta-analysis. Journal of Child and Family Studies, 27(3), 671-685. doi:10.1007/s10826-017-0932-0.

Wiggins, G., \& McTighe, J. (2011). Understanding by design: Guide to creating highquality units. Alexandria, VA: Assoc. for Supervision and Curriculum Development. 
William, D., Lee, C., Harrison, C., \& Black, P. (2004). Teachers developing assessment for learning: Impact on student achievement. Assessment in Education: Principles Policy and Practice, 11(1), 49-65. doi:10.1080/0969594042000208994. 